\title{
Lower Extremity Tremor Exacerbation due to Rivastigmine Administration for Treatment of Parkinson's Disease Dementia
}

\author{
Parkinson Hastalığı Demansı'nın Tedavisi için Uygulanan Rivastigmine Bağlı Gelişen Alt Ekstremite Tremor \\ Ekzaserbasyonu
}

\author{
Şeyma Kılıç, Nesrin Helvacı Yılmaz, Lütfü Hanoğlu, Fahriye Feriha Özer
}

Istanbul Medipol University, Faculty of Medicine, Department of Neurology, Istanbul, Turkey

\begin{abstract}
Rivastigmine is one of the approved effective treatments for Parkinson's Disease Dementia (PDD). Increase of upper extremity resting tremor is a common adverse effect seen in patients administered rivastigmine and is usually mild, not leading to treatment withdrawal. Rivastigmine patch was given to both of our patients diagnosed with PDD and they suffered from postural instability and lower extremity tremor that occurred while standing and disappeared with walking after the administration and increase dosage of the drug in a few months time. The lower extremity tremor disappeared markedly in both patients after the dose reduction. Disabling lower extremity tremor due to rivastigmine dosage increase has not been reported before. We want to draw attention to this rare side effect through these patients and mention not to quit the drug.
\end{abstract}

Key Words: Rivastigmine, tremor

Received: 06.17.2017

Accepted: 02.24 .2018

\section{ÖZET}

Rivastigmin Parkinson Hastalığı Demansı'nın (PHD) tedavisinde kullanılan etkili bir tedavilerden birisidir. Rivastigmin tedavisi uygulanan hastalarda sıklıkla üst ekstremitelerde istirahat tremor görülür ve genellikle hafiftir, tedavinin kesilmesine neden olmaz. Rivastigmin bant PHD tanısı almış iki hastamıza verdik ve doz artımı sonrası aylar içinde her ikisinde de ayağa kalkınca ortaya çıkan postural instabilite ve alt ekstremite tremoru gelişmiştir. İlacın dozunun azaltılması alt ekstremite tremoru belirgin şekilde kaybolmuştur. Rivastigmin doz arttırılmasına bağlı özürleyici alt ekstremite tremoru daha önce bildirilmemiştir. Bu olgu sunumunda nadir görülen bu yan etkiye dikkat çekmek ve ilacı kesmemek gerektiğini vurgulamak istedik.

Anahtar Sözcükler: Rivastigmin, tremor

Geliş Tarihi: 17.06 .2017

Kabul Tarihi: 24.02.2018

\section{INTRODUCTION}

Parkinson's Disease (PD) is clinically characterized by motor symptoms and spectrum of non-motor symptoms including neuropsychiatric problems and cognitive decline leading to dementia in up to $80-90 \%$ of patients (1). In prospective cohort studies, the prevalence of dementia in patients with PD is almost six times higher compared to control group without PD (2). Deficits of multiple neurotransmitters including serotonergic and noradrenergic; and decrease in dopaminergic and particularly cholinergic functioning lead to cognitive symptoms of Parkinson's Disease Dementia (PDD) $(3,4)$. Patients with PDD require specific treatment strategies based on neurotransmitter deficits. Cholinesterase inhibitors (ChEI) may have beneficial effects in PDD due to cholinergic dysfunction (5).

Several open-label studies and a recent double-blind study have suggested that ChEl could improve cognitive functions in PDD patients $(6,7)$. Reports revealed that rivastigmine improved all aspects of attention, and a subgroup analysis suggested that patients who had visual hallucinations at baseline seemed to draw more benefit from cholinergic treatment $(8,9)$. However, increasing cholinergic activity to alleviate cognitive dysfunction may exacerbate parkinsonian features.

In this case report, we present two PDD patients with disabling tremor of the lower extremities due to rivastigmine that has not been reported previously.

\section{CASE REPORT}

Case 1

Seventy-eight year-old man with a 5-year history of PD was admitted to our neurology outpatient clinic with complaints of forgetfulness and visual hallucinations. The patient had cognitive impairment for the last 2 years, hallucinations that appeared especially at nights. Other relevant medical history was arterial hypertension. The patient was administered levodopa 300 $\mathrm{mg} /$ day, quetiapine $25 \mathrm{mg} /$ day and clopidogrel $75 \mathrm{mg} /$ day; showed features of moderate parkinsonism, including masked face, retropulsion, bradykinesia, left-side-dominant rigidity and left hand resting tremor. Additional symptoms were hypophonia, stooped posture and freezing of gait. The patient's diagnosis was assessed by neurologists specialized in movement disorders according to the United Kingdom PD Society Brain Bank Clinical Diagnostic Criteria. Diffuse cortical atrophy and apparent bilateral frontal lobe atrophy were reported in cranial magnetic resonance imaging (MRI). Diagnosis was established as PDD based on symptoms of cognitive impairment and visual hallucinations. Rivastigmine patch $4.6 \mathrm{mg} / 24$ hour was added to the existing treatment regimen. No significant change in gait and cognition were observed following one month of levodopa and rivastigmine patch $4.6 \mathrm{mg} / 24$ hour therapy. However, the hallucinations were decreased. 
The patient's caregivers complained about agitation, insomnia and frequent drop attacks in the follow-up visit next month. Rivastigmine patch dosage was increased to $9.5 \mathrm{mg} / 24$ hour and the dosage was maintained for the following 3 months. The cognitive symptoms deteriorated and rivastigmine dosage was raised to $13.3 \mathrm{mg} / 24$ hour. The patient was readmitted to our hospital on the $14^{\text {th }}$ day of high dose rivastigmine, suffering from postural instability and lower extremity tremor that occurred while standing and disappeared with walking. High dose rivastigmine treatment was thought as the cause of tremor and the dosage was reduced to $9.5 \mathrm{mg} /$ day. Tremor of the lower extremities disappeared two weeks after the reduction of the rivastigmine dosage.

\section{Case 2}

Eighty-two-year old male PD patient was admitted to our outpatient clinic for bilateral hand tremor, gait disturbance, postural instability and amnesia. His complaints increased in the last few years. Periventricular ischemic areas were reported according to the cranial MRI. According to his neurological examination, PDD was the diagnosis. Levodopa $125 \mathrm{mg} 3$ times a day and rivastigmine patch $4.6 \mathrm{mg} /$ day were started. The tremor severity decreased and patient's gait worsened following two weeks of treatment. At the end of six months, rivastigmine dosage was increased to $9.5 \mathrm{mg} / \mathrm{day}$. After two months, the patient complained about tremor in lower extremities. Bilateral lower extremity tremor was prominent especially while standing. Rivastigmine dosage was decreased to $4.6 \mathrm{mg} /$ day. His complaints disappeared within 10 days.

\section{DISCUSSION}

Cognitive changes in PD are related to dopaminergic, cholinergic, noradrenergic and glutamatergic activity (10). ChEl improve dementia that results from cholinergic deficit in PD patients (11). Rivastigmine exhibits its effect by inhibiting both cholinesterase and butyrylcholinesterase (12). It is the optimal treatment for improvement of all aspects of attention, especially for patients suffering from visual hallucinations $(8,9)$.

Adverse effects of rivastigmine are known to be mostly cholinergic of which nausea and vomiting are the most commonly seen (7). Tremor is the third most commonly seen adverse effect (7). ChEl has been shown to increase tremor in $4 \%$ of Alzheimer patients $(6,7,8)$. In clinical trials, $27.3 \%$ of patients showed deterioration in parkinsonism symptoms and increase of tremor severity was the main symptom reported affecting $10.2 \%$ of the patients (7). Increase in resting tremor was especially observed; action and postural tremor enhancement were also reported (13). In another study, worsening of parkinsonian tremor in $10 \%$ of patients receiving rivastigmine was determined (14). Increased amplitude of resting tremor only in dominant hand (right) was shown in a study using accelorometry (15). However, these findings were observed to be usually permanent. Severe tremor is very rare and led to treatment withdrawal in $1.7 \%$ of the patients (7).

As a conclusion; lower extremity tremor has not been defined in previous case reports. Therefore, we aimed to emphasize that lower extremity tremor must be considered as a possible side effect in patients receiving high dose rivastigmine therapy by means of these two cases.
Conflict of interest

No conflict of interest was declared by the authors.

\section{REFERENCES}

1. Buter TC, van den Hout A, Matthews FE, Larsen JP, Brayne C, Aarsland D. Dementia and survival in Parkinson disease: a 12-year population study. Neurology 2008;70:1017-22.

2. Aarsland $D$, Anderson $K$, Larsen JP, Lolk A, Nielsen $H$, Kragh-Sørensen $P$. Risk of dementia in Parkinson's disease-a community-based, prospective study. Neurology 2001;56:730-6.

3. Leroi I, Brandt J, Reich SG Lyketsos CG, Grill S, Thompson R, et al. Randomized placebocontrolled trial of donepezil in cognitive impairment in Parkinson's disease. Int J Geriatr Psychiatry 2004;19:1-8.

4. Kövari E, Gold G, Herrmann FR, Canuto A, Hof PR, Bouras C, et al. Lewy body densities in the entorhinal and anterior cingulate cortex predict cognitive deficits in Parkinson's disease. Acta Neuropathol 2003;106:83.

5. Aarsland D, Laake K, Larsen JP, Janvin C. Donepezil for cognitive impairment in Parkinson's disease: a randomized controlled trial. J Neurol Neurosurg Psychiatry 2002;72:708-12.

6. Aarsland D, Cummings J, Larsen J. Neuropsychiatric differences between Parkinson's disease with dementia and Alzheimer's disease. Int J Geriatr Psychiatry 2001;16:184-191.

7. Emre M, Aarsland D, Albanese A, Byrne EJ, Deuschl G, De Deyn PP, et al. Rivastigmine for dementia associated with Parkinson's disease. N Engl J Med 2004;351:2509-18.

8. Wesnes KA, McKeith I, Edgar C, Emre M, Lane R. Benefits of rivastigmine on attention in dementia associated with Parkinson disease. Neurology 2005;65:1654-6.

9. Burn D, Emre M, McKeith I, De Deyn PP, Aarsland D, Hsu C, et al. Effects of rivastigmine in patients with and without visual hallucinations in dementia associated with Parkinson's disease. Mov Disord 2006;21:1899-1907.

10. Svenningsson P, Westman E, Ballard C, Aarsland D. Cognitive impairment in patients with Parkinson's disease: diagnosis, biomarkers, and treatment. Lancet Neurol 2012;11:697-707.

11. Tiraboschi P, Hansen LA, Alford M, Sabbagh MN, Schoos B, Masliah E, et al. Cholinergic dysfunction in diseases with Lewy bodies. Neurology 2000;54:407-11.

12. Lefèvre G, Sedek G, Huang HL, Saltzman M, Rosenberg M, Kiese B, et al. Pharmacokinetics of a rivastigmine transdermal patch formulation in healthy volunteers: relative effects of body site application. J Clin Pharmacol 2007;47:471-8.

13. Oertel W, Poewe W, Wolters E, De Deyn PP, Emre M, Kirsch C, et al. Effects of rivastigmine on tremor and other motor symptoms in patients with Parkinson's disease dementia: a retrospective analysis of a doubleblind trial and an open-label extension. Drug Saf 2008;31:79-94.

14. Richard IH, Justus AW, Greig NH, Marshall F, Kurlan R. Worsening of motor function and mood in a patient with Parkinson's disease after pharmacologic challenge with oral rivastigmine. Clin Neuropharmacol 2002;25:296-9.

15. Gurevich TY, Shabtai H, Korczyn AD, Simon ES, Giladi N. Effect of rivastigmine on tremor in patients with Parkinson's disease and dementia. Mov Disord 2006;21:1663-6. 